\title{
Effect of Estradiol-17 $\beta$ on Basal and hCG Stimulated Progesterone Secretion by Porcine Luteal Cells Isolated in Various Stages of the Luteal Phase
}

\author{
E. L. GREGORASZCZUK, AND D. ZIEBA \\ Laboratory of Animal Endocrinology and Tissue Culture, Institute of Zoology, \\ Jagiellonian University, 30-060 Krakow, Poland
}

\begin{abstract}
To explore the direct effect of estradiol-17 $\beta$ on pig luteal cells and its ability to counteract a gonadotropic stimulus, luteal cells were incubated in vitro in the presence of estradiol alone, human chorionic gonadotrophin (hCG) alone or estradiol combined with hCG. Luteal cells were collected at three different stages of the luteal phase (0-3 days after ovulation, early; 8-10 days after ovulation, mid; and 14-16 days after ovulation, late). Estradiol alone did not exert any effect on progesterone production by any of the 3 types of luteal cells.

Progesterone production by cells in the mid-luteal phase was enhanced by hCG in a dose dependent manner. High doses of estradiol combined with hCG significantly diminished production of progesterone by cells collected during the early luteal phase. The strongest inhibitory effect of estradiol on hCG stimulated progesterone production was observed in cultures of luteal cells in the midluteal phase. In contrast, $100 \mathrm{ng}$ of estradiol and the 10 and $100 \mathrm{ng} / \mathrm{ml}$ concentrations of hCG increased progesterone secretion over basal control values in cultured luteal cells in the late luteal phase. Differences in the production of progesterone in response to estradiol at different stage of the luteal phase suggest that different cellular mechanisms must be triggered in each luteal phase investigated. These data support a physiological role for estrogen in the regulation of the pig corpus luteum during its life span in the non-fertile cycle.
\end{abstract}

Key words: Estradiol, Pig, Corpus luteum, Progesterone secretion

(Endocrine Journal 41: 57-62, 1994)

THE ROLE OF estradiol- $17 \beta\left(\mathrm{E}_{2}\right)$ in the luteal function of domestic animals is still unclear. Estradiol has been considered luteotropic in the sow on the basis of evidence that exogenous $E_{2}$ administered either via systemic injection or intrauterine infusion can prolong the life span of the corpus luteum [1-3]. On the other hand injection of antisera to $E_{2}$ or estrone on day 10-21 of pregnancy had no effect on the maintenance of the corpora lutea or the initiation of placental attachment in the pig. [4]. In all in vivo studies purporting to demonstrate a direct luteotrophic effect of $E_{2}$, the possibility of an indi-

Received: July 2, 1993

Accepted: November 19, 1993

Correspondence to: Dr. E. L. Gregoraszczuk, Laboratory of Endocrinology and Tissue Culture, Institute of Zoology, Jagiellonian University, Karasia 6, 30-060 Krakow, Poland rect effect cannot be ruled out. Recent evidence suggests that estradiol produced by pig blastocysts during early pregnancy is an antiluteolytic rather than a luteotrophic factor since it decreases and changes the direction and secretion of prostaglandin $F_{2 \alpha}\left(P F_{2 \alpha}\right)$ secretion by the endometrium [2]. However, Geisert et al. [5, 6] showed that in addition to $E_{2}$ other biologically active substances such as prostaglandin $\mathrm{E}_{2}\left(\mathrm{PGE}_{2}\right)$ are involved in the maintenance of the corpus luteum in the pig. Van Meulen et al. [7] indicated that administration of a small physiological or supraphysiological dose of $\mathrm{E}_{2}$ into the lumen of the uterus did not result in the maintenance of $C L$ in non-pregnant gilts. Furthermore Ford \& Christensen [8] demonstrated a direct effect of $\mathrm{PGE}_{2}$, but not of $\mathrm{E}_{2}$ in protecting the CL against luteolysis induced by $\mathrm{PGF}_{2 \alpha}$. 
Our preliminary studies [9] showed that the administration of testosterone to the culture media of luteal cells collected in the mid-luteal phase caused an increase in estradiol secretion, which indicated the capacity of the corpora lutea to aromatize testosterone. On the other hand Gregoraszczuk [10] showed a decrease in the tissue concentration of progesterone and androgens and a simultaneous increase in estradiol in regressing corpora lutea which was suggested a signal for luteolysis. In addition, LH and FSH further stimulated estradiol secretion by luteal cells collected from the regressing corpora lutea [11].

To determine a possible direct effect of $E_{2}$ on luteal function in pig, the in vitro action of $\mathrm{E}_{2}$ on progesterone secretion by luteal cells isolated during the early, middle and late luteal phases was investigated.

In order to assess the potential luteotropic or luteolytic effect of estradiol, luteal cells were incubated with various combinations of estradiol and hCG.

\section{Materials and Methods}

\section{Animals}

Mature, cycling, slaughterhouse pigs were the source of ovaries. The stage of the cycle was determined with help of the tables by Schilling [12]. Luteal cells were collected from newly forming corpora lutea of the ovaries in the early luteal phase (day 0-3), from mature corpora lutea (day 810 ) and from regressing corpora lutea (day 14-16).

\section{Short term incubation}

Dissected corpora lutea were enzymatically dissociated according to the technique of Gregoraszczuk [13]. The cells were suspended in medium M 199 supplemented with $10 \%$ of calf serum at a concentration of $3.5-5.0 \times 10^{5}$ cells $/ \mathrm{ml}$ medium. They were incubated in multiwell plates (Corning) for $6 \mathrm{~h}$. Control cultures were grown in medium alone while other cultures were supplemented with:

1) estradiol $\left(E_{2}\right)$ in doses of either $1 \mathrm{ng} / \mathrm{ml}, 10$ $\mathrm{ng} / \mathrm{ml}$ or $100 \mathrm{ng} / \mathrm{ml}$,

2) hCG in concentration either $1 \mathrm{ng} / \mathrm{ml}, 10 \mathrm{ng} /$ $\mathrm{ml}$ or $100 \mathrm{ng} / \mathrm{ml}$,

3) estradiol combined with hCG in the same doses as above.

The cultures were incubated in quadriplicate in each of the 3 experiments.

After $6 \mathrm{~h}$ incubation, all cultures were terminated and the media were frozen at $-20^{\circ} \mathrm{C}$ for further steroid analysis.

\section{Reagents}

Medium M199, calf serum, trypsin $(0.25 \%$ solution in calcium and magnesium free PBS) were the products of the Laboratory of Sera and Vaccines (Lublin, Poland).

Penicilin, streptomycin and mycostatin were obtained from GIBCO (USA), and standards crystaline estradiol 17 $\beta$ and hCG (SIGMA).

\section{Steroid analysis}

Progesterone was analysed by the radioimmunoassay according to Abraham et al. [14]. A high specific antibody raised in sheep against $11 \alpha-$ hydroxyprogesterone, hemisuccinate coupled to bovine serum albumin was used. The cross-reaction with pregnenolone was $2.9 \%$. All other steroids that were tested showed less than a $1 \%$ crossreaction. $\left[1,2,6,7-{ }^{3} \mathrm{H}\right]$ progesterone, Radiochemical Center, Amersham, England, sp. act $80 \mathrm{Ci} /$ mmol was used as the tracer. The sensitivity of the assay was $50 \mathrm{pg}$. The coefficients of variation within and between assays were less than $2.5 \%$ and $15 \%$ respectively.

The data for progesterone were computed in nanograms per $10^{5}$ cells per $6 \mathrm{~h}$ of incubation. The statistical difference between control and experimental cultures was calculated by student's $t$-test.

\section{Results}

The effect of exogenous $E_{2}$ on progesterone production in vitro

Under basal in vitro conditions, progesterone production by early luteal phase cells isolated on days $0-3$ was significantly greater than that of mid and late luteal phase cells $\left(800 \mathrm{ng} / 10^{5}\right.$ cells $/ 6 \mathrm{~h}$, $300 \mathrm{ng} / 10^{5}$ cells $/ 6 \mathrm{~h}, 22.7 \mathrm{ng} / 10^{5}$ cells $/ 6 \mathrm{~h}$ respectively) (Fig. 1). There was no response by three investigated types of luteal cells in terms of progesterone secretion to exogenous $E_{2}$ as shown in Fig. 1 . 


\section{The effect of exogenous $h C G$ on progesterone production}

Progesterone production by mid-luteal phase cells was significantly enhanced by the presence of
$1 \mathrm{ng}, 10 \mathrm{ng}$ and $100 \mathrm{ng}$ hCG $(P<0.05, P<0.01$, $P<0.001$, respectively) (Fig. 2). In contrast progesterone production by early and late luteal phase cells was not stimulated by the three doses of hCG used (Fig. 2).

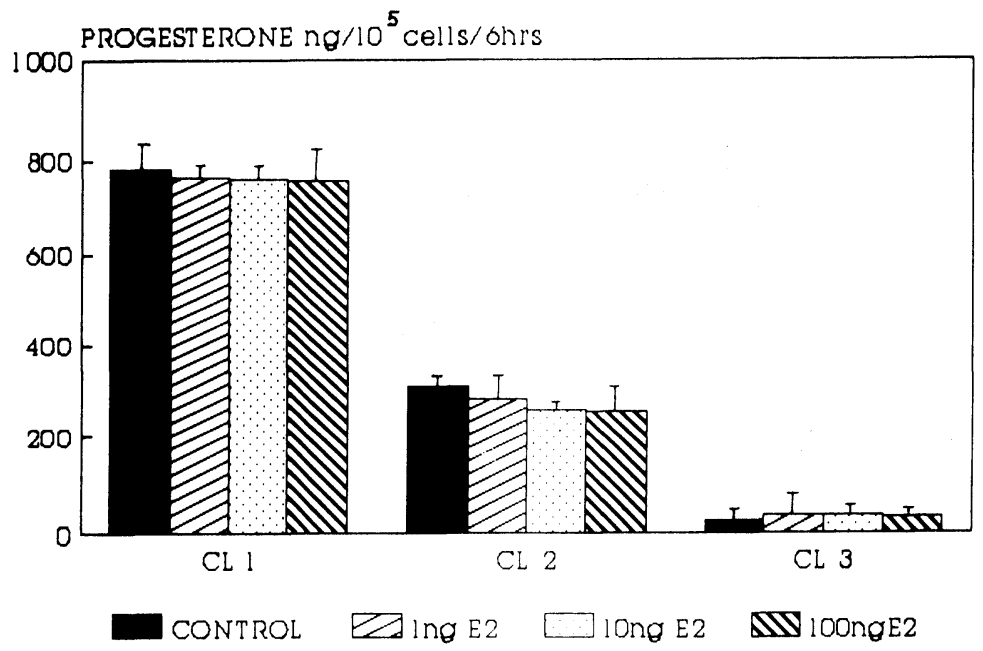

Fig. 1. Secretion of progesterone by luteal cells collected from pig during early (CL 1), mid (CL 2) and late (CL 3) luteal phases in the presence of various concentrations of exogenous estradiol. Production is expressed as ng progesterone released per $10^{5}$ cells during $6 \mathrm{~h}$ incubation. Values are the means for 3 experiments.



Fig. 2. Influence of various doses of hCG on progesterone production by pig luteal cells obtained during early (CL 1), mid (CL 2) and late luteal phases (CL 3 ). Production is expressed as ng progesterone released per $10^{5}$ cells during $6 \mathrm{~h}$ incubation. Values are the means for 3 experiments. ${ }^{*}, P<0.05 ;{ }^{* *}, P<0.01$; ${ }^{* *}, P<0.001$. 
The effect of $E_{2}$ and $h C G$ on stimulated progesterone production

The effect of various concentrations of estradiol on hCG stimulated progesterone production by early luteal phase cells is shown in Fig. 3a.

Although luteal cells collected from early corpora lutea did not respond to the doses of hCG used with increased production of progesterone, high doses of hCG combined with $\mathrm{E}_{2}$ significantly diminished secretion of progesterone $(P<0.05)$.

The stimulatory effects of $1 \mathrm{ng}, 10 \mathrm{ng}$ and 100 $\mathrm{ng} / \mathrm{ml}$ concentrations of hCG on progesterone secretion were completely blocked by 1,10 and 100 $\mathrm{ng} / \mathrm{ml}$ concentrations of estradiol (Fig. $3 \mathrm{~b}$ ).

The effect of estradiol on hCG stimulated progesterone production by late luteal phase cells is summarized in Fig. 3c. The combinations of $100 \mathrm{ng}$ of estradiol and the 10 and $100 \mathrm{ng} / \mathrm{ml}$ concentrations of hCG increased progesterone secretion over control values. In contrast, the 1 and $10 \mathrm{ng} / \mathrm{ml}$ concentrations of estradiol had no significant effect at any concentration of hCG.

\section{Discussion}

The first evidence showing that, in pig during the luteal phase, estradiol can originate from the corpora lutea has been obtained by Weiss et al. [15], who demonstrated that the porcine luteal tissue in vitro is capable of synthesizing estradiol. This was confirmed by Gregoraszczuk [13, 16, 17]. Gregoraszczuk [10] showed that the concentration of estradiol in homogenates of corpora lutea in the early luteal phase was very low $(100 \mathrm{pg} / \mathrm{ml})$. It was higher in homogenates of mature corpora lutea $(340 \mathrm{pg} / \mathrm{ml})$ and very high in regressing corpora lutea $(50 \mathrm{ng} / \mathrm{ml})$. Cultured luteal cells are able to secrete large basal amounts of estradiol not only when isolated during corpus luteum regression but also when collected from partially developed (5-8 days after ovulation) and mature corpora lutea (8-10 days after ovulation) [10]. They also clearly show that in vitro steroid production by different types of corpora lutea does not entirely reflect the in vivo situation. This was apparently related to the luteinization and differentiation of cells in the course of tissue culture. In order to see whether estradiol can directly influence pig luteal function, the in vitro effect of estradiol on progesterone production by cells isolated during early, middle and late luteal phase was evaluated.



b) MIDDLE LUTEAL PHASE



c) LATE LUTEAL PHASE

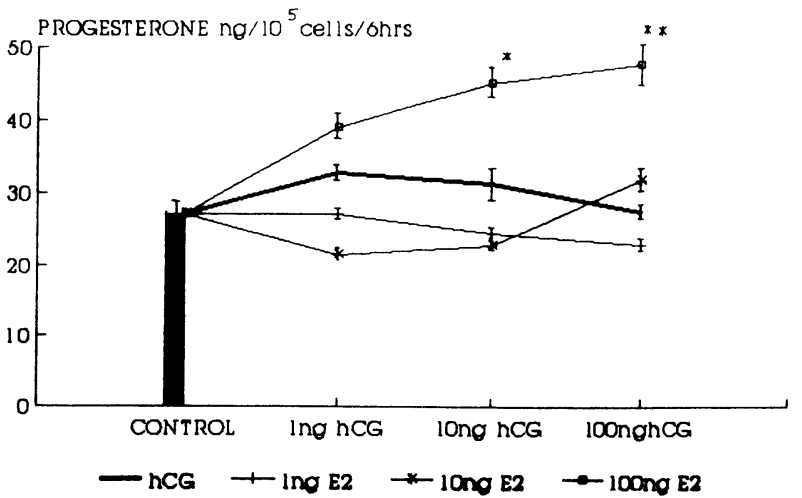

Fig. 3. Influence of estradiol on hCG stimulated progesterone production by pig luteal cells isolated during early middle and late luteal phases. Cells were incubated in the presence of hCG plus 0 (control), 1, 10 and $100 \mathrm{ng} \mathrm{E}_{2} / \mathrm{ml}$. Values are the means for 3 experiments. ${ }^{*}, P<0.05 ;{ }^{* *}, P<0.01$. 
In addition, to study the ability of estradiol to counteract a luteotropic stimulus, luteal cells were studied with cultures treated with hCG. In the current study three distinct effects on progesterone production by luteal cells as a function of the estrogen concentration present during incubation were observed: firstly estradiol did not exert any effect on progesterone production by any of the 3 types of luteal cells investigated. So the increased estrogen synthesis during the late luteal phase is not a prerequisite for spontaneous luteolysis in the pig. Secondly, increased progesterone production under the influence of exogenous gonadotropin (hCG) was sensitive to estradiol inhibition in cultured luteal cells collected from mature corpora lutea. This is in accordance with the findings of Tekpetey and Armstrong [18] who observed that in the pig, $\mathrm{E}_{2}$ decreased $\mathrm{LH}$-stimulated $\mathrm{P}_{4}$ production by small luteal cells and basal $\mathrm{P}_{4}$ production by both cell types, particularly at $72 \mathrm{~h}$ incubation, but increased $\mathrm{P}_{5}$ accumulation, suggesting an inhibitory effect on the enzyme $3 \beta$-hydroxysteroid dehydrogenase. We must remember that in vivo the estradiol content in CL during midluteal phase is still low. It was postulated that high circulating LH levels protect elevated estradiol secretion [9]. This was not related to the absence of substrate. High amount of androgens was observed in homogenates of the CL isolated during the midluteal phase [10]. Thirdly, however low estrogen doses ( 1 and $10 \mathrm{ng} / \mathrm{ml}$ ) consistently antagonized the stimulatory effect of hCG during regression, while high estrogen doses $(100 \mathrm{ng} / \mathrm{ml})$ had a visible stimulatory effect on progesterone secretion during the late luteal phase.
It is still difficult to conclude that there is a stimulatory effect of estradiol combined with hCG on progesterone production by cells collected during the late luteal phase, keeping in mind that hCG alone and estradiol alone had no effect on progesterone production and the fact that in this stage of luteal phase the basal progesterone level is very low. The data of Ford \& Christenson [8] suggest that the major antiluteolytic effect of $E_{2}$ on estrogen-induced pseudopregnant gilts is to decrease uterine release of $\mathrm{PGF}_{2 \alpha}$ into the peripheral circulation, rather than to have a direct protective effect at the level of the CL.

Would it be a great heresy to speculate that this might be an intraluteal luteotropic mechanism which could be started in cases when pregnancy occurs, taking into consideration the data of Rosenkrans et al. [19] indicating that catechol estrogens and $E_{2}$ may inhibit prostaglandin synthesis and modify the PGE: PGF $_{2 \alpha}$ during the establishment of pregnancy in pigs?

Further experiments are necessary to answer this question.

\section{Acknowledgements}

The authors are grateful to Professor S. Stoklosowa for her guidance and constant interest in this work as well as to Dr. A. Wojtusiak for technical assistance. This work was supported by grant KBN PB 0243/S3/92 as well as by the SMA fund of the World Health Organisation, Special Programme of Research, Development and Research Training in Human Reproduction.

\section{References}

1. Gardner ML, First NL, Casida LE (1963) Effect of exogenous estrogens on corpus luteum maintenance in gilds. J Anim Sci 22: 132-134.

2. Bazer FW, Thatcher WW (1977) Theory of maternal recognition of pregnancy in swine based on estrogen controlled endocrine versus exocrine secretion of prostaglandin $\mathrm{F}_{2 \alpha}$ by the uterine endometrium. Prostaglandins 14: 394-401.

3. Conley AJ, Ford SP (1989) Direct luteotrophic effect of oestradiol-17 $\beta^{\prime}$ on pig corpora lutea. J Reprod Fert 87: 125-139.

4. Robertson HA, Dwyer RJ, King GJ (1980) Effect of oestrogen antisera early in gestation on pregnancy maintenance in the pig. J Reprod Fert 58: 115-120.

5. Geisert RD, Renegar RH, Thatcher WW, Roberts RM, Bazer FW (1982) Establishment of pregnancy in the pig. Interrelationship between preimplantation development of the pig blastocyst and uterine endometrial secretion. Biol Reprod 27: 925-939.

6. Geisert RD, Zavy MT, Wettermann RP, Biggers BG (1987) Length of pseudopregnancy and pattern of uterine protein release as influenced by time and duration of oestrogen administration in the pig. $J$ Reprod Fert 79: 163-172. 
7. Van der Meulen J, Elsaesser F, Oudenaarden CPJ, Helmond FA (1991) Effect of intra-uterine oestradiol-17 $\beta$ administration on inter-oestrous interval in the pig. Anim Reprod Sci 24: 305-313.

8. Ford SP, Christenson LK (1991) Direct effect of oestradiol-17 $\beta$ and prostaglandin E-2 in protecting pig corpora lutea from a luteolytic dose of prostaglandin F-2 $\alpha$. J Reprod Fert 93: 203-209.

9. Gregoraszczuk EL (1991) The interaction of testosterone and gonadotropins in stimulating estradiol and progesterone secretion by cultures of corpus luteum cells isolated from pigs in early and midluteal phase. Endocrinol Japon 38 :229-237.

10. Gregoraszczuk EL (1992) The dynamics of steroid hormone secretion and morphological changes of porcine corpora lutea isolated in 4 differnt times of the luteal phase. Endocrine Regulation 26: 187-194.

11. Gregoraszczuk E (1992) Is porcine corpus luteum autonomous with respect to $\mathrm{LH}, \mathrm{FSH}$ and PRL through the entire luteal phase? Proceedings of 12 International Congress on Animal Reproduction 2: 951-953.

12. Schilling E (1974) Stages of ovarian function in the sow. In: Veterinary Medical Review. N.G. Elwert Univesitas und Verlagsbuchkandlung MrburgLahn, 59.
13. Gregoraszczuk E (1983) Steroid hormone release in cultures of pig corpus luteum and granulosa cells: Effect of LH, hCG, PRL and estradiol 17 $\beta$. Endocr Exper 17: 59-63.

14. Abraham GE, Swerdloff R, Tuchlinsky D, Odell WD (1971) Radioimmunoassay of plasma progesterone. J Clin Endocr Metab 32: 619-654.

15. Weiss JR, Brinkley HJ, Young EP (1976) In vitro steroidogenesis in porcine corpora lutea. J Anim Sci 42: 121-130.

16. Gregoraszczuk E (1989) Effect of various doses of FSH upon luteal cell function in tissue culture. Endocr Exp 23: 195-203.

17. Gregoraszczuk E (1990) Different response of porcine large and small luteal cells to PRL in terms of progesterone and estradiol secretion in vitro. Exp Clin Endocrinol 96: 234-237.

18. Tekpetey FR, Armstrong DT (1991) Steroidogenic response of rat and pig luteal cells to estradiol-17 $\beta$ and catecholestrogens in vitro. Biol of Reprod 45: 498-505.

19. Rosenkrans CF, Paria BC, Davis DL, Milliken G (1992) Synthesis of prostaglandin by pig blastocysts cultured in medium containing estradiol or catechol estroge. Prostaglandins 43: 309-319. 